\title{
THE SKUNK RIVER WAR (OR TALLY WAR)
}

Keokuk County, August, 1863

\section{By C. C. Stiles, Superintendent of Archives Division}

Among the manuscripts and printed documents on file in the different divisions of the Historical, Memorial and Art Department of Iowa may be found materials relating to any subject incident to the history of the state. In writing this article I have used materials found in each of the following divisions: Public Archives, Newspaper, and Library divisions.

During the Civil War period the correspondence, reports, etc., show the intense excitement existing attendant upon the raising of troops to be sent to the front, and the home guards for the purpose of maintaining peace at home, also letters informing the authorities of the organizing of secret societies to aid the South in their struggle against the loyal states.

'The clashings of the two elements were frequent, deeds of lawlessness often occurred, property was destroyed and lives taken. But the reins of government during this period were held by the firm unwavering hands of our "Old War Governor," Samuel J. Kirkwood, aided by Adjutant General N. B. Baker, and the state passed through this trying period without any stains that could not be erased from its untarnished history.

In the records of the legislature I found a petition by J. B. Shollenbarger relating to the subject of this article. Following is an exact copy :

To the Senate and House of Representatives of the State of Iowa:

Your petitioner respectfully represents that in the latter part of July, 1863, there was great excitement in Keokuk County, Iowa, in relation to the raising of troops to put down the war of the Southern Rebellion, that one Sype Tally professedly a Democrat took strong grounds in opposition to the war and went about the country making speeches that were called treasonable in opposition to the raising; after one of these inflamatory speeches there was tremendous excitement accompanied by the discharge of fire arms, in the opinion of the petitioner not for the purpose of taking life but for the purpose of intimidation. One of 
these shots whether by intention or not, is not known, killed the said Sype 'Tally, he dying instantly by a ball through the head. By this act the entire county was thrown into great commotion. The friends of $\mathrm{Mr}$. Tally declared vengeance and threatened to destroy the town of Sigourney, situated fourteen miles from the scene of the murder, because of the presumed Republicanism of a majority of the inhabitants of said town of Sigourney. Our late governor, Samuel J. Kirkwood, being apprised of the above facts, instantly called out troops and with artillery, repaired to Sigourney to put down what was called the Ially War. 'The Governor arrived some hours or more before the arrival of his troops. When prominent town people thought it best to appoint a committee of five to wait on the insurgents at Camp Tally (in the Hoobs Grove) and occupy their time and attention until the troops should arrive. In the opinion of Governor Kirkwood one hour would be sufticient. Judge Harned, T. A. Morgan, James Adams, Geary Wilkinson, and J. B. Shollenbarger (the petitioner) were appointed on said committee. Parenthetically it may be said here that immediately before this time your petitioner edited a Douglas Democratic paper ${ }^{1}$ but at the same time thoroughly endorsed the war and favored all legitimate means to secure its successful termination in favor of the Union.

'That he had at that time served over a year in the Union Army, that my son Hiram W. Shollenbarger had enlisted in the Thirty-third Regiment, and that my partner, Samuel B. Evans, served his term of enlistment in the Army.

At the last moment two of said committee declined to go, and the other two being on duty left for myself, alone, to do what could be done (if anything). Single and alone in the uniform of the United States your petitioner repaired to the camp of the insurgents (Hobbs Grove). 'There I moved that Austin Jacobs act as chairman, then called for speeches from William Bunt and D. N. Henderson and others. My hour had expired and I returned to town where I saw, with my own eyes, an assault on my press by the man that filed the information against the Copperheads, as they were termed, with an iron poker, telling the boys to stand aside until he would give that "Dammed Copperhead Hell," which was Ben Franklin's bust on the top of my press. He threw the bust out of its socket and it being of cast iron came down heavy on the floor and broke the plastering down in the room, now occupied by Cunningham \& Anderson as a hardware store. By calling for speeches and by other devices the belligerents were detained until the troops arrived.

The insurgents, having (in part) come to town, the Governor made to them one of his characteristic speeches, plain, patriotic and practical. He told them in conclusion that all unlawful conduct on their part must inevitably be put down. He counselled a quiet acquiescence in the laws

\footnotetext{
1[Sigourney] Iowa Democrat, established in 1858 by $\mathrm{S}$. B. Evans and Farra. In 1860 Farra sold his interest to J. B. Sollenbarger. In 1862 botl proprietors enlisted in the Union Army and the paper was suspended.-ANNAis of Iowa, Vol. XVI, p. 191.
} 
of the land and said if necessary the governors of friendly states near would furnish him assistance and that even if required the government of the United States was pledged to furnish a portion of the Army and Navy to put down any insurrection, even in a small county like Keokuk, lowa. The speech being concluded your petitioner called for three cheers for Governor Kirkwood, the first was faintly given but the last most vociferously and uproariously given. The troops of the Governor were obliged to have quarters and a portion of them, by necessity, were located in my office against my will and consent $I$, knowing the character of the soldier, offered my parlor with carpet in it rather than get my type all pied, but nevertheless, they quartered a lot of soldiers in my office who pied all the type, then in form, which was the whole paper tax list all new type, and while there so quartered observing by unmistakable signs that mine was a Democratic office and totally ignorant of the character of my democracy, these soldiers destroyed my press and scattered the type about the office and threw a share of it into the street and on the sidewalk and after my re-enlistment in the Ninth Iowa Cavalry I recaptured one of my printer sticks in Arkansas from a young boy who told me he got it in my office in Sigourney and that he had been informed that I was a Rebel and I have the same stick in my trunk now as a war relic. Any printer knows that after this was done what remained was almost worthless.

Your petitioner has given the foregoing brief history and statement of facts for the purpose of appealing to the justice of your honorable body for reimbursement in amount equal to the value of above named losses. If ever property was lost in the service of his country and deserved reimbursement it occurs to your petitioner that this is one of the cases. At a moderate valuation the foregoing property was richly worth $\$ 1000.00$. It is proper to add that $\$ 200.00$ of said amount has already been paid to your petitioner by a previous legislature.

Before concluding I shall add that $I$ am now very near sixty years of age. Since the War in which I took part your petitioner has been a great sufferer from diarrhea and scurvy, and that I also become afflicted. with a semi-paralysis of the left side which has in a great degree impaired my mental faculties and prevents me from doing clerical duty which I might otherwise do.

Your petitioner represents that he is not a pensioner, although he has not seen a well day since he was first discharged; that mentally and physically he is a wreck and totally unable to maintain himself by manual labor. Your petitioner respectfully solicits such reimbursement as your honorable body may ascertain is just and due in his case according to the true equity in his case. Petitioner further states that through inability to maintain himself by manual labor that he has been compelled to occupy quarters at the National Soldiers Home at Milwaukee, Wisconsin, since the 15th of August, 1879. Your petitioner represents that he served two terms of service during the late War, that he served about fifteen months in the Fifth Iowa Volunteers and 
afterwards his three years in Ninth Iowa Cavalry Volunteers as will appear by the Adjutant General's Report.

JOSEPH B. Schollex BARGER.

State of Wisconsin

County of Milwaukee ss.

Subscribed and sworn to before me and in my presence by J. B. Shollenbarger late of Fifth Iowa Volunteers and Ninth Iowa Cavalry Volunteers.

\section{WoolletT,}

Notary Public.

This petition was presented January 22, 1880, to the legislature by Cyrus H. Mackey ${ }^{2}$ of Sigourney, then member of the House of Representatives from Keokuk County. The committee to whom it was referred reported back to the House that it "Be - not granted."

To give the reader a clearer understanding of the beginning and cause of the Skunk River War I call your attention to an article on the subject published in 1880 on pages $443-48$ of a History of Keoluk County on file in the Library Division of the Historical, Memorial and Art Department of Iowa.

In 1848, there came to Keokuk County a family by the name of Tally. They had previously resided in Tennessee, and by birth and education were in sympathy with the "peculiar institution" of the South. Upon the breaking out of the war they arrayed themselves on the side of the anti-war party, believing, as many thousands throughout the North did believe, that unless the erring sisters could be peaceably prevailed upon to remain, they should be allowed to go in peace.

One of the family, Cyphert Tally, was a young man of more than ordinary brilliancy of intellect, and though possessed of meager education, was an orator of great force and ability. A short time prior to the war he had entered the ministry of the Baptist church, and as far as appears from the evidence of those most likely to know, was, in his private character as an individual and in his public character as a minister, above reproach. Some time after the beginning of the war he

2Cyrus H. Mackey was born in Lewiston. Illinois, August 22, 1837, and died in Sigourney, Iowa, July 17, 1909. He was with his parents, James and Abigail Mackey, in their removal to Springfield, Keokuk County, Iowa, in 1855 . He read Iaw with the firm of Sampson (E. S.) \& Harned (S.) of Sigourney and was admitted to the bar in 1858 and began practice in Sigourney. He entered the Union Army August 10, 1862 , as lieutenant colonel of the Thirty-third Iowa Infantry, was promoted to colonel August 18, 1863, was wounded severely April 30, 1864, at Jenkins Ferry, Arkansas, and was mustered out July 17, 1865, at New Orleans. He returned to Sigourney and resumed his law practice in which he attained distinction, and in which ne continued until shortly before his death. He was a representative in the Pighteenth General Assembly, 1880, was the Democratic nominee for Congress from the Sixth District in 1882, was the Democratic nominee for attorney general of Iowa in 1986, and again in 1890, was more than once a delegate to a national convention of lis party, and in 1900 was a candidate on the Democratic ticket for presidential elector at large. 
was called upon to preach the funeral of a soldier who had died in the Union Army. He consented to do so, the place where the appointment was made being Mt. Zion Church, in Steady Run Township.

When the congregation had assembled, and after Tally had taken his place in the pulpit, the question of his loyalty was raised by some of the brethren and, at their suggestion, another Baptist minister who was present went into the pulpit and informed him that his loyalty was questioned and if rumors were true as to certain sentiments which he was reported to have uttered, there were those in the audience who preferred not to listen to his discourse. After a short consultation Tally arose and announced that as there appeared to be objections to his preaching from that pulpit he would dismiss the congregation and those who desired to hear him should go to a certain schoolhouse nearby. He thereupon left the church and started for the schoolhouse followed by the greater part of the audience, but upon his arrival at the place found the schoolhouse locked and the subdirector refused to give up the key. They then went to a grove where the funeral sermon was preached and the audience dismissed. The circumstances attending the preaching of this funeral gave rise to bitter disputes and bickerings in the neighborhood and party feeling ran high. Encouraged by his friends Tally became still more pronounced in the expression of his political views and soon after abandoned the pulpit and took the stump. Numerous opposition meetings were held in the county and Tally was invariably the chief speaker. He soon became quite a hero and received and accepted invitations to speak in various parts of the adjoining counties. On every hand he was extolled and lionized by those of a like political faith. Thus flattered and petted it is not at all remarkable that as young a man as Tally should become bold to commit some very indiscreet deeds and make some very unwise statements. In his public speeches he used language which was very offensive to the war party and threats were made in some parts of the county that Tally could not speak there. Whenever such threats were made the friends of Tally seemed to be particularly anxious that he should speak at those very places, and urged forward by the injudicious counsels of these friends improved the very first opportunities which presented themselves in making good the assertion that he could speak and would speak at any place in the county where he chose to. To these meetings people from all parts of the county would flock, many of them well armed. Such was the condition of affairs when occurred the tragic event which put an end to the eventful career of young Tally.

On Saturday, August 1, 1863, a Democratic mass meeting was held near English River, in Keokuk County. The speaking occurred in a grove, about one half mile from town. The chief speaker was 'Tally. Several hundred persons were present at this meeting, most of whom had come in wagons, in the bottom of which was hay or straw, and therein secreted were arms of different kinds which fact was developed at a later hour in the day. Speeches were made during the forenoon, 
and as some Republicans were present, party spirit ran high. As an illustration of the excitement, it is related that in stripping of butternut badges the clothing was almost torn from a couple of ladies present who displayed the objectionable emblem. Wild and perhaps idle threats were made that the party would come up in the afternoon and clean out the town of South English, which was quite a radical stronghold. Reports of these were carried up into town, where, from the balcony of a hotel, a Republican was addressing a meeting of his party, and in the town the radical feeling was also quite strong. To be prepared for emergencies, the citizens were armed as far as there were weapons for their use. In the afternoon the Tally party came up to the town in wagons. In the front wagon were several men, including Tally, who stood up in the rear part.

The Republican meeting had just closed, and arms were freely displayed. Some person warned Tally that he had best not go through the town, as there would be trouble; but he claimed he meant no injury to anyone, and merely asked the privilege of the street. As the first wagon came into the crowd, there were cries from the street of "coward!" "copperhead!" "afraid to shoot!" etc. Previous to this time no weapons had been displayed by the party in the wagon, but upon these cries they came up from the bottom of the conveyance. Just then the street became so crowded that it was necessary to stop the wagon for a moment. At that instant a citizen accidentally, as he claimed, discharged one barrel of his revolver into the ground. This was the occasion for a general firing, and it is marrelous that the loss of life was not much greater. It has been estimated that one hundred and fifty shots were fired, which is evidently a great exaggeration. Tally stood in the back part of the wagon, with revolver and bowie knife in hand; he evidently fired twice, as two chambers were empty, when he fell from the wagon dead, having been shot once through the head and twice through the body. One of the horses attached to the wagon was wounded, which caused the team to run, and probably avoided more serious consequences. 'The only other party seriously wounded was a man by the name of Wyant, who recovered. Upon receiving the fatal shot, 'Ially fell prostrate in the wagon, and it was not known that he was dead until the driver of the team succeeded in controlling the horses, when an examination revealed the fact that life had already departed.

The next day being Sunday, preparations were being made at the home of Tally, whither his remairis had been conveyed the previous evening, for the funeral, while messages were sent in every direction informing Tally's friends of his death, and calling upon them to avenge it. At the solicitation of certain influential citizens of Sigourney and elsewhere, a committee, consisting of S. A. [B.] Evans, Wm. H. Brunt, Presley Doggett and others, proceeded to the Tally neighborhood on the Monday following. When they arrived 'Tally had already been buried, and about one hundred people, from various parts of the county had assembled, determined on revenge. The committee said they had 
come in the interest of peace, and that they were authorized to guarantee the arrest and speedy trial of the person or persons who killed 'Tally. Their words seemed to have had little effect on the crowd, and they departed. All this time wagon loads of men were on their way from Wapello, Mahaska and Poweshiek counties to the place of rendezvous on Skunk River. Probably as many as one hundred and fifty came from Mahaska County alone. These volunteers formed what is currently known as the Skunk River Army.

By Monday night affairs began to present quite a dangerous aspect to the people of South English and Sigourney, and that night two citizens of the latter place made their way to Washington on horseback, and there, procuring a hand car, proceeded to Wilton Junction, where they took a train for Davenport, in order to consult Governor Kirkwood, who was known to be there at that time. They found the Governor early on 'Tuesday morning, and stated the facts; his first reply was a verbal order for three hundred stands of arms, which he then gave the gentlemen in writing, and told them to procure the arms and return to Keokuk County. One of the gentlemen replied: "My God Governor, am I to understand you [want us] to return home and shoot down our neighbors?" The Governor replied: "On second thought, I guess I'll go myself." And go he did, just as he was, without collar or necktie, and attired in the careless dress which he was accustomed to wear when at his regular employment. The Governor arrived on Wednesday evening at Sigourney; troops and a couple of cannons followed soon after. That night he made a speech in front of the Court House.

The popular story of the Governor's threat of minie balls and canister to the Skunk River Army and of their terror-stricken flight from their camp is a myth, the truth being that there was no considerable number of armed men nearer English River than Skunk River, which is sixteen miles from the town. The project of armed resistance had been practically abandoned before Governor Kirkwood reached the town, many of the Mahaska County troops having returned to their homes on Monday or Tuesday. It is probable that there were still some men assembled at the time of Governor Kirkwood's visit, and that his proclamation was read to them which gave rise to the more extravagant story. There was nobody badly frightened on either side, and no paricular cowardice manifested. It is highly probable that if Bill Tally had continued as leader that the result would have been quite disastrous. The Skunk River Army has been variously estimated at numbers ranging from five hundred to four thousand; the first figure is probably not far from the truth. . . The grand jury at the following term of the District Court, took the Tally matter under consideration, but no one was indicted, and up to the present time it has not been found out who fired the fatal shot. It is highly probable, however, from the nature of the wound, that the shot was not an accidental one, but well aimed, and from an unerring hand. 
From the Adjutant General's Report for the year 1863 on file in the Public Archives Division of the Historical, Memorial and Art Department I submit the following:

\section{Governor Kirkwood:}

South English, Aug. 2, 1863.

Dear Sir:-Our town was thrown into great commotion yesterday, in consequence of treasonable acts committed by the "Copperhead" party, resulting in the death of probably three or four persons, including their leader-Tally. There were near a hundred shots fired on either side. They retired, making threats to return, reinforced, and burn the town, \&c. We can say that we were not the aggressive party. We bore their insults (butternut badges) as well as listened to their treasonable talk with patience, until they came through the village with their guns, and knives, \&c., exhibited, when some one called out "cowards!" which was repeated by several, when they commenced firing into the crowd; and as there had been so many threats made by them before, it was natural for us to stand on the defensive. We very much desire you to take measures to protect our town, by sending us aid. If you cannot do so, send us arms.

$$
\begin{gathered}
\text { Yours, Respectfully, } \\
\text { Allex Hale } \\
\text { Wm. Cochran, } \\
\text { Thos. J. Moorma }
\end{gathered}
$$

South English, Aug. 3rd, 1863.

To His Excellency Gov. Kirkwood, or Adjt. Gen. Baker:

Dear Sirs:-Excitement still continues here. Our ambassadors, that we sent from here yesterday to come to an accommodation with the friends of Tally, are detained now over twelve hours longer than the time appointed for their return, or at least the time expected. We have rumors from different sources of an attack on our town, and are expecting it hourly. We have not over two hundred armed men, if that, and the arms are nothing but shotguns and rifles, a few revolvers, knives, \&c. We beg of you to reinforce us immediately. If you cannot possibly do this, send us available arms, as many as you can. We have organized.

Your Humble Servants,

A. HaL,e,

T. J. Moorman,

Committee appointed to communicate with you.

Adjutant General's Office, Davenport, Iowa, Aug. 4th, 1863.

Hon. S. J. Kirkwood:

On Saturday, August 1st inst. a riot occurred in the town of South English, in the Coounty of Keokuk, Iowa, resulting in the death of one 
person, and severely wounding several others. Since that time the county has been in a feverish state of excitement. A large body of men, armed with rifles and shotguns, have formed, and are camped in the western part of the county, threatening to take the law into their own hands, and murder, plunder, burn and destroy, unless their unreasonable demands are complied with. According to their own statements, this force thus assembled in violation of law, amounts to over three thousand men, and from my own knowledge of the matter I think there must be at least one thousand men in the county unlawfully under arms. Our citizens are in very great fear for the safety of person and property, and the county funds, valuable public records, and the greater portion of the funds of private individuals, have been removed from the county for safe keeping. Under these circumstances we feel ourselves justified in calling upon the state authorities for aid in dispersing this lawless assemblage of men.

\section{J. H. SANDERs.}

\section{SPECIAL ORDER}

Head Quarters, Sigourney, Aug. 8th, 1863.

The troops now here will remain until notified by the sheriff of Keokuk County that they will be no longer needed.

The soldiers will avoid all occassion of quarrel with the citizens, and are hereby strictly enjoined not to injure or molest any citizen, either in person or property, unless in execution of orders and in the line of duty.

The military force at this place will be strictly subordinate to the civil authority, and will be under the direction of the sheriff. They are only to protect and assist the officers of the law in the performance of their duties.

Captain Satterlee will be in command of all the troops at this place and will see that this order is strictly obeyed.

By order of the Governor.

M. M. Trumbull, Asst. Adjt. Gen.

\section{COMPANIES CALIED OUT}

List of companies engaged in suppressing disturbances in Keokuk Co., August, 1863:

\begin{tabular}{|c|}
\hline 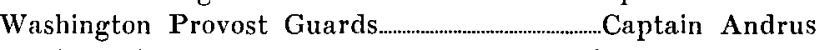 \\
\hline Brighton Guards............. \\
\hline Richland Home Guards.... \\
\hline Fairfield Prarie Guards..... \\
\hline Fairfield Union Guards \\
\hline Abingdon Home Guards _ C Captain W. D. \\
\hline
\end{tabular}


Mt. Pleasant Infantry Captain Jericho

Mt. Pleasant Artillery Captain Burr

Sigourney Home Guards Captain Price

To give the reader a clearer understanding of the attitude taken by Governor Kirkwood on the subject I herewith submit the following from the Governor's Journal of 1862-1863 now on file in the Public Archives Division of the Historical, Memorial and Art Department of Iowa:

\section{EXTRACTS FROM THE JOURNAL OF \\ Gov. Samuel J. Kirkwood}

1862-1863

Executive Office Iowa
Iowa City, Aug. 3rd, 1863.

James M. Adams

Sheriff Keokuk Co. Iowạ.

Sir:

Information has reached me that on Saturclay last a conflict occurred at a political meeting had at South English in your county which resulted in the death of one or more persons and it is represented to me that there is danger of an attack on the people of that place in revenge for the death of the person or persons killed.

Such events as that of Saturday, \& that said to be threatened are dangerous to the peace of the state and must if possible be prevented. The laws must be maintained \& enforced.

Investigate the occurrences of Saturday last \& present conditions of affairs there. The local authorities should at once take the necessary steps to ascertain the facts attending the death of the person or persons killed and the guilty persons on one side or the other. But I wish you $\&$ it is your duty to prevent further conflicts and breaches of the peace. The people of South English must be protected if in danger-A mob must not be permitted to take the law into their own hands and mete out punishment to those whom they may consider guilty. This would produce retaliation \& further confliçt.

Examine into all the facts clearly and carefully and report to me in writing.

It is your duty to prevent further disturbance and so far as is in my power I will hold you responsible for a failure to perform that duty. You have the power to summons to your assistance a sufficient force to preserve the peace and enforce the laws and should do so promptly.

Very Respectfully

Your Obt. Servant, SAMUel J, KIRKWood. 
Executive Office Iowa

Iowa City, Aug. 5, 1863.

N. B. Baker,

Adjt. Genl, of Iowa.

Sir :

You will immediately upon receipt of this order send to the sheriff of Washington County by the express train of tomorrow morning \& by cxpress, forty stands of arm with a due allowance of ammunition. Be sure to send the arms by express and the early train tomorrow for Washington. Send with the arms by the express messenger the enclosed letter to the sheriff of Washington County. Don't fail in the prompt cxecution of this order.

Very Respectfully

Your Obt. Servant,

SAMUEL J. KiRKWOOD.

P. S. Pay express charges.

Executive Office Iowa

Iowa City Aug. 3rd, 1863.

Sheriff of Washington County, Iowa.

Sir:

There will be delivered to you with this letter forty stands of arms $\&$ an amount of ammunition for the same.

You will deliver these forty stands of arms and the ammunition to the written order of Allen Hale, Wm. Cochran and Thos. Morseman or of any two of them. They live in South English, Keokuk County and $I$ am informed there is danger of an attack on that place and a serious breach of the peace on account of an unfortunate occurrence there on Saturday last. These arms are intended for their defence.

\section{Very Respectfully \\ Your Obt. Servant, SAMUEL J. Kinkwoov.}

Executive Office Iowa

Iowa City, Aug. 3rd, 1863.

Messrs. Allan Hale,

Wm. Cochran \& Thos. Morsman,

South English, Keokuk Co., Iowa.

Gentlemen:

I have learned with regret the unfortunate occurrence at your place on Saturday last, and also that there is danger of further conflict and disturbance in consequence. I, of course, cannot determine where the fault is or who are the responsible parties, but it is very clear this is a matter to be determined. by the law and not by a mob. If it shall turn out that 'Ially was unlawfully killed, the law must show who is the guilty person and must inflict the punishment. If a mob of his friends are permitted to determine who is guilty and to inflict punishment it is just as probable that the innocent will suffer as the guilty. Besides 
such proceedings unsettle society and render every man's life and property insecure.

I have sent to the sheriff of Washington County forty stands of arms and ammunition for the same for you. These arms are intended only and strictly for the defense of your people against any lawless attack on your town by a mob and for the purpose of aiding the lawful authorities in enforcing the laws and maintaining the public peace. 'They must not be used for any other purpose or in any other manner. You must keep your people strictly on the defensive and clearly within the law. You must not resist the execution of legal process but must aid in enforcing \& executing it. If you are attacked by a mob of riotous and lawless men you will of course defend yourselves.

The public mind is much excited by the acts of mischievous and designing men and it becomes lawabiding and peaceful citizens not to add to this excitement. Act prudently and cooly and lawfully.

I trust that the threatened danger may pass over without further disturbances. I have written the sheriff of your county to act in this matter. Until his arrival I must trust to your judgment \& discretion. Upon his arrival act under his authority.

\section{Very Respectfully}

SayreeL J. KiRKwood.

\section{ORGANIZING AND ARMING VOLUNTEER COMPANIES}

\section{From Governor Kirkwood's Biennial Message to the Tenth General} Assembly

I became satisfied during the early part of last summer that design-ing men in this, as in other loyal states, were making preparations for an armed resistance to the authority of the general government. 'The law of Congress, providing for a draft to fill the ranks of the Union Army, contained a provision that was eagerly seized upon to array the poorer of our people against the government upon the specious pretence that the object of the law was to discriminate between the rich and the poor, to the injury of the poor.

The action of the government, in frceing and using the slaves in the rebel states for the suppression of the Rebellion, was represented as a scheme, by the government, to overrun the free states with the freed slaves, to the prejudice of the interest of the poor white man.

The government had in some instances, arrested and temporarily imprisoned or sent beyond our lines, persons whose restraint the public safety required; and this was interpreted to mean, an intention on the part of the government to break down all the defenses of civil liberty, and to establish a despotism. The entire policy of our government, as interpreted by these men, was that the war was waged, not for the preservation of the Union, but for the abolition of slavery; that the object of the government, in seeking to abolish slavery was to bring the freed slaves north, and force their labor into competition with that of the poor white man; that by the so-called Conscription Law, the 
govermment sought to force only the poor men of the country into the ranks of the army, to effect these objects so prejudicial to their interests, and that while these objects were being effected, the government intended to overthrow our free institutions, and establish in their stead a despotism.

It is passing strange that intelligent men could be found so wicked as to make these statements, and that other men could be found so ignorant and foolish as to believe them. But so it was. These statements were made through the press and from the stump, in the most violent and exciting language, apparently with all the earnestness of conviction, and thousands of honest, but deluded men believed them, and in consequence entertained feeling of deep hostility to the government. In this excited state of the public mind, secret societies were organized in many, if not all of the loyal states, the members of which were, to some extent, secretly armed for the avowed purpose of protecting themselves against what were called "arbitrary arrests," but as I am satisfied with the intent upon the part of the leaders to bring their members into armed collision with the general government, in case any attempt should be made to enforce the draft. The natural rcsult of these teachings and this action, was seen in the bloody riot that occurred in the chief city of the Union, and in similar smaller outbreaks in other places.

Under these circumstances, my duty seemed to me to be plain and clear. I was bound to see the enforcement of the laws and the preservation of peace and good order; and when organized action was being taken throughout the state to prevent the one, and violate the other, I did not think my duty permitted me to wait until the evil was upon us before I took steps for its prevention. I accordingly called upon the loyal men of the state, who were willing to aid in the enforcement of the law, to organize a volunteer military company in each county of the state. Such companies were promptly organized, in most of the countics, of loyal and substantial citizens, and as they were organized, I placed arms and ammunition in their hands to make their organization effective. By these means a sufficient force was provided to preserve the peace of the state and insure the enforcement of the law of Congress, without weakening our army facing the enemy by withdrawing any portion of it for that purpose, and in my judgment, this state of preparation to preserve the peace, tended largely to prevent its violation.

There was but a single occasion in which it was necessary to use the force thus organized. About the first day of August last, as a number of persons who had been attending a political meeting near the village of South English, in Keokuk County, were returning through that village, a collision took place between them and other persons in the village, in which a Mr. Tally, who had addressed the meeting, was killed. The friends of Tally, instead of appealing to the laws and the officers of the law for redress, chose to assume that the officers of the 
law would not do their duty. They sent runners to various points and in a short time had gathered, near Sigourney, the county seat of the county, a large body of armed men, who undertook to dictate to the officers of the law for what offence and in what manner, the persons charged with killing Tally should be tried and punished. Much alarm existed throughout the county. The county funds were sent off for safety, and arrangements were made to send away the county records; and orderly and law-abiding people were in great anxiety and terror. $\Lambda \mathrm{s}$ soon as these facts were made known to me, I at once ordered to Sigourney a sufficient number of volunteer companies, of infantry and artillery, to give protection to the people and the officers of the law, and to show those assembled for unlawful purposes, not only the hopelessness, but the danger of their attempt to overawe the authorities; and I am glad to be able to inform you that the display of force was sufficient to effect the desired object. As soon as it became known that a force was being gathered to sustain the law, the unlawful assemblage quictly dispersed, order and tranquility were restored, and the officers of the law were left unmolested in the performance of their duty.

The companies thus organized and armed are still in existence and, should any further legislation be decmed neccssary for their efficiency, I recommend that such legislation be had.

In closing this subject, I would return my thanks to the officers and men ordered by me to Sigourney and South English, on the occasion referred to, for the promptness with which they responded to the order, and their soldierly conduct and bearing while on duty.

In the Annals of Iowa, Vol. IX, pages 142-45, will be found an article on this subject by Hon. Frank W. Eichelberger, who at that time, 1863, was representing the Muscatine Journal. 'This article I am presenting in full from the fact it presents clearly the action taken by Governor Kirkwood in the episode:

\section{GOVERNOR KIRKWOOD AND THE SKUNK RFVER WAR}

By Hon. Frank W. Eichelberger

During the dark days of the summer of 1863, when Grant was investing Vicksburg and Lee marching on Pennsylvania, there existed in portions of Keokuk, Poweshiek and Wapello counties a large number of southern sympathizers, who had from the outset of the war made a fierce opposition to its prosecution.

A man named Tally, living near Ioka in Keokuk County, a Baptist preacher, made himself a leader among this element by his blatant, disloyal speeches in different parts of the country, rendering himself obnoxious to the Union-loving portion of the community. He usually went armed with a couple of revolvers and a bowie knife and openly defied the authorities to arrest him. The fall of Vicksburg and defeat of Lee at.Gettysburg scemed to embitter him and hị harangue became more violent and threatening. 
On the first of August, accompanied by seventy or eighty men in wagons, all armed, he went to South English in Keokuk County, and held a meeting in the outskirts of the village. Whilst this was in progress, a Republican meeting was organized in the street opposite the hotel, whicl was addressed by a man named Settler, from Mt. Pleasant, who happened to be at the hotel. During the progress of this meeting, Tally and his crowd in wagons drove through the meeting, exhibiting butternut and copperhead pins, which were the recognized badges of disloyalty in the North at that time. A wounded soldier named Moorman, seized one of the men wearing a butternut and stripped it off and was proceeding to serve others in the same manner when he was seized by some of them. His father went to his rescue and discharged his revolver. At this, Tally raised up in his wagon and gave the word to fire, at the same time firing his own revolver into the crowd and a regular fusilade was discharged by his armed followers, but singular to relate without hitting anyone. I was there the next day and saw many bullets imbedded in the hotel front. The firing was returned and Tally was killed and one of his men wounded. On the fall of their leader they drove off, vowing to return and hang a number of the citizens and burn the town.

Word was sent to Washington, Iowa, where Col. N. P. Chipman, chief of staff for General Samuel $R$. Curtis, happened to be at home on a short furlough. He left immediately for South English, whither I accompanied him in the interests of the Muscatine Daily Journal of which paper I was then city editor.

On our arrival Col. Chipman organized a company, erected barricades and prepared to resist any effort to take the town. During the day companies of state militia arrived from Washington and others came in from Poweshiek and Iowa counties, and the town was turned into a military camp, with Col. Chipman in command and J. F. McJunkin of Washington, afterwards attorney general of Iowa, as adjutant.

In the meantime a mob of six or seven hundred men had gathered in the bottoms of Skunk River armed with all kinds of weapons from shotguns to meat axes. They demanded that ten of the best citizens. of South English should be arrrested and immediately tried, charged with the crime of murder in the first degree, and threatening to march on the town and burn it, and seize the men themselves and hang them, unless their demand was complied with.

The messenger sent by them, discovering the preparations made for their reception, returned and reported that the men were willing to give themselves up to the proper authorities for trial, which under the circumstances of Col. Chipman's preparation was accepted.

They were arrested by Sheriff Adams, had a preliminary hearing before a justice of the peace and were bound over in the sum of $\$ 1000.00$ each for their appearance at the next term of the District Court. The army of the Skunk was dispersed and Col. Chipman's forces sent home and it was supposed the affair ended. But during the night 
another mob of nearly a thousand men gathered on Skunk River bottom near Sigourney and threatened to march on that place and destroy it unless the men bound over at South English were immediately brought to Sigourney and placed on trial. There was great excitement at Sigourney, the business houses were closed and nearly every man turned out to defend the place. There was no railroad or telegraph line to Sigourney at the time.

Mr. Sanders, the clerk of the court, who afterwards established and conducted Sander's' Stock Journal at Chicago, drove to Washington and took an engine from there to Muscatine, where he got into telegraphic communication with Governor Kirkwood. I went back on the engine and drove to Sigourney, finding the town in a state of great excitement, patrolled by a company of home guards, only half of them armed. 'The town was filled with ugly, scowling, armed rioters from the rendezvous on Skunk River and things looked pretty squally.

During the night Governor Kirkwood came in from Washington accompanied only by Col. Trumbull of his staff, afterwards colonel of the Ninth Cavalry. 'They drove direct to the Court House and Governor Kirkwood at once proceeded to make a speech.

It is only once in a lifetime that a man is permitted to hear such a speech, and especially to such an audience under such circumstances. The grand old man seemed to be inspired; he was utterly fearless, although apparently in imminent danger from the rough crowd that surrounded and threatened at times to hang him, hissing and howling curses at him, which however failed to interrupt his speech. And such a speech! Its like never came from the mouth of any other governor of any state.

It was far from ladylike, in fact would hardly do for print, but was vigorous, virile and to the point, filled with good old English and interspersed with an occasional round mouth-filling epithet as he referred to the Rebels. It was exhilarating, exciting but fearsome to see that rugged, fearless, earnest, grand man standing up in the middle of the night hurling denunciations and threats to such a mob. He told them that he had come to see that the law was enforced; that the people of South English would be fairly tried and if guilty punished, but not by such a scoundrelly mob as confronted him; that he had reason to believe that they were drawn together not so much to punish crime or see that it was punished, as to throw obstacles in the way of the government in putting down the rebellion; that he didn't propose to have any fire-in-the-rear rebellion in Iowa and unless they dispersed before morning he would have them shot down like dogs; that he had ordered troops which were on their way, and when they arrived the next day they would shoot, and shoot straight, and shoot leaden bullets, not blank cartridges; that he would put down this mob if he had to kill every mother's son of them-although that was not exactly the name he applied, but it would not be polite to give it verbatim.

His appearance and bravery cowed them and they commenced to 
slink away, and before the Governor would go to bed most of them had left town. 'The next morning a company from Muscatine and during the day others arrived from Mt. Pleasant, Washington and other towns, and by evening there were ten companies of militia quartered in and around the town and the mob had entirely dissolved and gone home.

I have always thought that there would have been bloodshed if Governor Kirkwood had not fearlessly met the crisis.

A number of the rioters were arrested and bound over, charged with exciting riot, but they together with the South English prisoners, were released and all prosecution was wisely dropped at the next term of court.

Following are two articles, one from the Weelly Courier of Muscatine and one from the Muscatine Journal. These articles are submitted to portray the attitude taken by the newspapers and the people, on each side, of the great controversy at that time:

\section{THE DISTURBANCE IN KEOKUK COUNTY}

From the Muscatine Weekly Courier, August 6, 1863

On Saturday, the first day of August, the Democrats of Keokuk County, in obedience to the suggestion made by the State Central Committee, assembled in mass convention near South English, for the purpose of ratifying the proceedings of the Democratic State Convention. Returning from the meeting many of the Democrats passed through the town of South English, where they were set upon by so-called Union men, and the badges worn by some of the Democrats were torn off and trampled under foot by abolition rioters.

Shooting followed this raid upon Democratic badges, and the first shot fired was by a "Union man." The principal speaker at the Democratic meeting was then killed, and two other Democrats mortally wounded-and as far as we have been able to learn, not one "Union man" or abolitionist was in any manner injured. Yet abolition newspapers, instigated by the friends of perdition, gravely charge that Democrats are to blame for this wicked and murderous outrage upon the persons of Iowa citizens. A mob of abolitionists get together, armed to the very teeth, and intercept Democratic speakers and others as they return from a public meeting, and wickedly and fiendishly kill and murder three of those Democrats, and then abolition editors, desiring to hire these pretended "Union men" to shed more blood, call upon them to exterminate the Democrats, assuring the fighting abolitionists that "Iowa is unsafe for" Democrats.

$O$, blind and infatuated tool of a wicked despotism! When will you get your eyes open to see the enormity of the crime you are committing? You sit in your editorial chair and applaud abolition miscreants for shooting down in cold blood, Democrat speakers, and then lecture 
those Democrats for interfering to prevent themselves from being exterminated! What wily fiend has taken posession of your heart that - you can thus madly provoke the angry spirit of a mob when all good men are trying to allay the growing storm? You, Mr. Journal, for twelve long months, have advocated mob law in this city-You have threatened quiet and peaceable citizens with hanging-you have tampered with the mob spirit which your own infernal malice has created in our midst-You have, by repeated falsehoods and calumniation, sought to bring Iowa citizens into disfavor with the masses, so that a mob incited by your howlings, would kill and murder them-You have urged the mob to destroy property as well as lives, and in every manner that your own wicked passions could plot, you have aimed at substituting the hellish acts of mobs and demons, for law and order. In obedience to your teachings your party in an adjoining county have organized a mob-and as you directed in your issue of yesterday, they have "fired" at Democrats and killed and murdered them-and you, poor, driveling tool of mad masters-you approve the bloody deed and threaten vengance on those who will not quietly stand and be murdered. Poor sniveller, seek your hole and hide yourself, and no longer contaminate the free air of heaven with your pestilential breath. You want mobs do you?

\section{A DEAD DESPERADO}

From the Muscatine Journal, republished in the Keokuk Gate City, August 10, 1863

Rev. S. Tally, of Ioka, Keokuk County, who was killed in the difliculty at South English on Saturday last, was about thirty years of age. He was a Baptist preacher, but we are informed, had no charge and spent his time mostly in traveling through Keokuk and adjoining counties making inflammatory appeals to the people against the government. He was known throughout that region as a reckless character, and among the ignorant classes who compose the Copperhead faction was a most dangerous man.

We are informed by J. H. Williamson, Esq., of Louisa County, that in June last he had a public discussion on polities with Tally. The latter was then armed to the teeth, having a large bowie knife conspicuously suspended from a belt around his waist, and also a pistol in his vest pocket and one or two in his coat pockets. The burden of his remarks was the tyranny of the administration and the duty of the Democrats to take up arms against it.

This is the character of the man whom the Muscatine tory sheet mildly denominates "a Democratic speaker," and upon whose death, while in the act of unprovokedly shooting down his fellow citizens and calling upon his followers to imitate his example, it takes occasion to charge the administration and its friends with a "fiendish murder."

We want no stronger evidence of the deep-seated sympathy for treason in the mind of the editor of the Courier than this fact. 
Copyright of Annals of Iowa is the property of State of Iowa, by \& through the State Historical Society of Iowa and its content may not be copied or emailed to multiple sites or posted to a listserv without the copyright holder's express written permission. However, users may print, download, or email articles for individual use. 